\title{
Knowledge Sharing In Perspective Of Tri Kaya Parisudha And Its Effect On Value Engineering Construction Projects
}

\author{
Made Novia Indriani ${ }^{1}$, I Nyoman Arya Thanaya ${ }^{2}$, Nyoman Yudha Astana ${ }^{3}$ and A.A.Gde Agung Yana ${ }^{4}$ \\ ${ }^{1}$ Student of Doctoral Program Engineering Science Udayana University, Denpasar, Bali, Indonesia \\ ${ }^{2,3,4}$ Lecture of Doctoral Program Engineering Science Udayana University, Denpasar, Bali, Indonesia \\ *Email :madenovia@gmail.com
}

\begin{abstract}
Knowledge is the implementation of information and is convinced can be used for decision making. In this 21st century the success of an organization depends very much on the knowledge they have and how to utilize existing knowledge. The objectives of the research are to know and understand the effect of tacit knowledge and explicit knowledge in the Tri kaya Parisudha perspective on the value engineering of construction projects and to know and understand the influence of explicit knowledge mediating the relationship of tacit knowledge to the value engineering of construction projects. Quantitative analysis used is multivariate analysis using structural equation modeling or SEM with a variance-based or component-based approach called PLS (Partial Least Square). Tacit knowlege in manacika perspective significantly influences explicit knowledge in wacika and kayika perspectives, as well as tacit knowlege and explicit knowledge in manacika, wacika and kayika perspectives significantly influence construction project value engineering. Whereas explicit knowledge partially mediates between tacit knowledge to value engineering on construction project.
\end{abstract}

Index Terms - Knowledge sharing, Tri Kaya Parisudha, Value engineering, Construction projects.

\section{INTRODUCTION}

$\mathrm{K}$ nowledge is one of the most important and valuable organizational resources that contribute to sustainable competitive advantage[1]. Knowledge is the implementation of information that is convinced can be used for decision making. Accordance with the [2] states that knowledge management functions to improve the ability of members of the organization to learn from their environment and combine knowledge in an organization to create, collect, and maintain the organization's knowledge.

For many organizations, knowledge management has become a key success factor [3]. However, many organizations have not yet succeeded in applying the concept of knowledge management. One reason is the lack of success of the organization to encourage knowledge sharing. Research from [4] states that knowledge management which consists of tacit knowledge and explicit knowledge is a series of activities used by organizations or companies to identify, create, explain, and distribute knowledge to be reused, known, and studied within the organization.

Opinions about the knowledge management approach are in accordance with [5] that knowledge is divided into two main types, namely tacit knowledge and explicit knowledge. Tacit knowledge is something that is stored in the human brain, something that is experienced but difficult to transfer to others because it is stored in the minds of each individual member of the organization. While explicit knowledge is something contained in documents or other storage areas other than in the human brain.

So that knowledge sharing if it is associated with the concept of Hindu teachings namely Tri Kaya Parisuda which consists of manacika (mind), wacika (words) and kayika (deeds) can be used as guidelines in carrying out activities. The concept of Tri Kaya Parisuda teaches that the existence of a good mind will underlie good words, so that the deeds that are manifested in the form of ideas [6].

In addition to producing a cost efficiency, value engneering is also an analytical method that can produce innovation and competitive advantages in a project or product in the context of discussion [7].

\section{A. Knowledge Sharing}

Culture of social interaction that involves the exchange of knowledge, experience and skills in an organization is a term of knowledge sharing activities [8]. The success of knowledge management initiatives is significantly dependent on sharing knowledge [9]. Knowledge sharing can reduce the influence of complications of the construction project [10], and to overcome complex tasks, employees in construction companies need to share 
knowledge and expertise within and between groups [11]. Knowledge management system is an important input and knowledge sharing is the key to the process, then organizational innovation and performance are the output of the process. Knowledge sharing activities are not only related to the interaction of members of the organization, the exchange of ideas, experiences among all members [12]. According to [13], knowledge sharing activities are one of the activities of sharing human resource knowledge in organizations that contribute to the application of knowledge, innovation and improving company performance. While [14] also stated that top management in organizations is an important factor that influences knowledge sharing in organizations. According to [15], his research stated that management must facilitate easy communication and knowledge sharing among employees to obtain new learning and improve work performance effectively and efficiently. Tacit knowledge is one of the important assets in the construction industry, because of its significant role in driving innovation and creating value[16]. Tacit knowledge is valuable, intangible assets, and it is one of the most important competitive advantages for individuals, teams, and organizations. This is especially true in the context of the construction industry, in Indonesia where most activities are knowledge-intensive and knowledge needs are tacit [17]. One measurement used is the tacit and explicit dimensions to measure the perception of knowledge sharing. According [18] in his research, in the form of knowledge in a company must enable the conversion of knowledge from tacit to explicit knowledge. So this study refers to the research of [19], that knowledge sharing consists of two things, namely:

1. The dimension of tacit knowledge sharing has several indicators, namely: the frequency of gathering and sharing knowledge based on experience and expertise, the frequency of gathering and sharing knowledge with everyone and everywhere, and failure is a valuable experience.

2. The dimension of explicit knowledge has several indicators, namely: the frequency of sharing reports and documents to members of the organization, the frequency of preparing reports with members of the organization, the frequency of collecting report documents, motivating knowledge sharing mechanisms, participating in training and development programs, utilizing information technology facilities.

Research from [20], which examines the influence of tacit knowledge which is one component of knowledge sharing on the ability of innovation, The results show that the ability of innovation is highly dependent on the level of development of tacit knowldge in organizations, organizations must know the internal factors that are components tacit knowledge.

\section{B. Tri Kaya Parisudha}

Tacit knowledge if we associate it with the concept of Tri Kaya Parisudha in accordance with the concept of manacika (thinking), whereas explicit knowledge is a form of knowledge that has been documented, easily stored, propagated, disseminated and studied with understanding and absorption. So the explicit knowledge approach is more in line with the concepts of wacika (words) and kayika (actions). Good knowledge management will be based on positive perceptions and thinking (manacika) and disseminated, documented, reproduced (wacika and kayika) right [21].

\section{Value Engineering}

Value Engineering intends to provide something optimal for the amount of money spent using systematic techniques to analyze and control the total project costs. In the early $1960 \mathrm{~s}$, value engineering began to be applied to the construction industry. At that time the contractors were required to reduce project costs without reducing the quality and function of the construction products. To overcome this, the contractors and their clients began to apply the value engineering method when designing construction products. Although in the end it can reduce costs, but the real purpose of the value management method is to get the maximum value (benefits / results) of a product or service from the budget that has been provided, or to get the value for Money. The application of value engineering to project implementation according to [22] is expected to be able to:

1) Increase benefits by not adding costs.

2) Reduce costs by maintaining benefits.

3) A combination of both.

In essence, innovation is doing something different and has added value (value added).

\section{METHOD}

This research was conducted on a construction project contractor who had finished and was working on a project in Bali, which was determined based on a purposive sampling technique. The population in this study is a construction project contractor totaling 10 people per one construction project. With 10 total construction projects spread across Bali that have been completed and are in the implementation stage. The method of analysis using the Partial Least Square (SEM-PLS) Structural Equation Model with the Smart PLS 2.0 M3 program is recommended to use a sample of between 30 to 100 respondents [23]. So that in this study the number of samples used as respondents was 100 respondents. Questionnaire and quick interview were conducted to collect perception data from respondents. The hypothesis in this study, as in Figure 2.1 following:

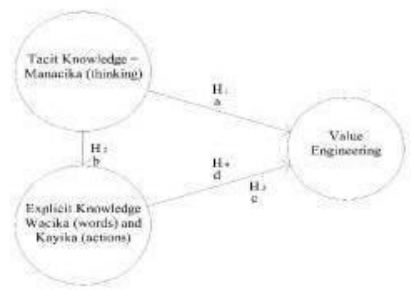

Figure 2.1 Research hypothesis Source: researchers (2020) 


\section{RESULT AND DISCUSSION}

This research uses Partial Least Square (PLS) analysis technique. This stage consists of: 1) evaluation of measurement models (outer models) to determine the validity and reliability of indicators measuring latent variables, and 2) evaluation of structural models (inner models) to determine the accuracy of the model with goodness of fit models

\section{A. Evaluation of measurement models (outer model)}

Aims to find out the validity and reliability of the indicator indicators that measure latent variables namely; tacit knowledge variable (X1), explicit knowledge (Y1), variable value engineering (Y2). Evaluation of the measurement model is done with check convergent and discriminant validity of construct indicators and composite reliability for indicator blocks.

1. Composite reliability

Composite reliability aims to test the value of reliability between indicator blocks of the construct shape it. Composite Results reliability is said to be good, if the value is at above 0.70 . Composite reliability testing aims to test the validity of instruments within a specific research model for reflexive indicators. Test result composite reliability is presented in Table 3.1 follows:

Table 3.1 Composite Reliability Test Results

\begin{tabular}{|l|l|}
\hline Variable & Composite Reliablity \\
\hline Explicit Knowledge & 0.910 \\
\hline Tacit Knowledge & 0.870 \\
\hline Value Engineering & 0.901 \\
\hline
\end{tabular}

Source: data processed (2020)

From Table 3.1 above shows that the third composite reliability value variables that make up the model research all above 0.70. This matter means that all indicators are reflexive which forms the research model is reliable.

\section{Convergent Validity}

Convergent validity calculation aims to find out the items that make up the indicator of all latent variables. Convergent validity test results measured based on the amount of value loading factor (outer loading) of the construct indicator. Test result convergent validity is presented in Table 3.2. following :

Table 3.2 Test Results For Convergent Validity

\begin{tabular}{|l|lr|l|l|l|}
\hline Code & Indicator & Exp-K & Tacit-K & VE \\
\hline Exp- & share & knowledge & 0.824 & & \\
K1 & $\begin{array}{l}\text { and } \\
\text { through roblems } \\
\text { meeting }\end{array}$ & regular & & & \\
& $\begin{array}{l}\text { and a right } \\
\text { way }\end{array}$ & & & \\
& responsible & & & \\
Exp- & share & knowledge & 0.783 & & \\
\hline
\end{tabular}

\begin{tabular}{|c|c|c|c|c|}
\hline K2 & $\begin{array}{l}\text { through documents } \\
\text { in the form of } \\
\text { reports routine }\end{array}$ & & & \\
\hline $\begin{array}{l}\text { Exp- } \\
\text { K3 }\end{array}$ & $\begin{array}{l}\text { prepare reports on } \\
\text { real each activity }\end{array}$ & 0.804 & & \\
\hline $\begin{array}{l}\text { Exp- } \\
\text { K4 }\end{array}$ & $\begin{array}{l}\text { collect documents } \\
\text { and photos of } \\
\text { activities } \\
\text { reporting materials }\end{array}$ & 0.778 & & \\
\hline $\begin{array}{l}\text { Exp- } \\
\text { K5 }\end{array}$ & $\begin{array}{l}\text { eager for sharing } \\
\text { knowledge with a } \\
\text { right } \\
\text { responsible way }\end{array}$ & 0.719 & & \\
\hline $\begin{array}{l}\text { Exp- } \\
\text { K6 }\end{array}$ & $\begin{array}{l}\text { attend various } \\
\text { competency } \\
\text { development } \\
\text { programs fairly in } \\
\text { all divisions }\end{array}$ & 0.729 & & \\
\hline $\begin{array}{l}\text { Exp- } \\
\text { K7 }\end{array}$ & $\begin{array}{l}\text { utilize information } \\
\text { technology facilities } \\
\text { to share } \\
\text { knowledge with a } \\
\text { right and } \\
\text { responsible way }\end{array}$ & 0.772 & & \\
\hline TK1 & $\begin{array}{l}\text { absorb knowledge } \\
\text { based on experience }\end{array}$ & & 0.716 & \\
\hline TK2 & $\begin{array}{l}\text { giving ideas, } \\
\text { perceptions and } \\
\text { ways of thinking } \\
\text { well }\end{array}$ & & 0.783 & \\
\hline TK3 & \begin{tabular}{lrr} 
share & \multicolumn{2}{r}{ knowledge } \\
based & on & their \\
insights & & and \\
expertise & &
\end{tabular} & & 0.807 & \\
\hline TK4 & $\begin{array}{l}\text { gathering } \\
\text { knowledge based } \\
\text { on expertise }\end{array}$ & & 0.797 & \\
\hline TK5 & $\begin{array}{ll}\text { experience } & \text { failure } \\
\text { as learning } & \end{array}$ & & 0.676 & \\
\hline VE1 & $\begin{array}{l}\text { benefits increase by } \\
\text { not adding costs }\end{array}$ & & & 0.823 \\
\hline VE2 & $\begin{array}{ll}\text { benefits } & \text { are } \\
\text { maintained but } & \text { costs are reduced }\end{array}$ & & & 0.897 \\
\hline
\end{tabular}




\begin{tabular}{|l|l|l|l|l|}
\hline & & & & \\
\hline VE3 & $\begin{array}{l}\text { benefits can } \\
\text { increase but the } \\
\text { costs required are } \\
\text { reduced }\end{array}$ & & & 0.882 \\
\end{tabular}

Source: data processed (2020)

Test results in Table 3.2. above shows that all outer loading values of the construct indicator have values above 0.5 . So it can be concluded that this measurement fulfills convergent validity requirements.

\section{Discriminant Validity}

In addition to testing convergent validity, in the PLS analysis it also tests disclaimer validity. The testing method is compare the square root value of average variance extracted (vAVE) each construct with correlation between constructs other in the model. If value initial measurement of both methods better than value other constructs in the model, then can be concluded that construct it has a discriminant value good validity or vice versa. Results discriminant validity testing is presented in Table 3.3 (a) and table 3.3 (b) the following

Table 3.3 (a) Calculation VAVE

\begin{tabular}{|l|l|l|}
\hline Variable & $\begin{array}{l}\text { Average Variance } \\
\text { Extracted (AVE) }\end{array}$ & VAVE \\
\hline Exp-K & 0.598 & 0.773 \\
\hline Tacit-K & 0.574 & 0.757 \\
\hline VE & 0.753 & 0.867 \\
\hline
\end{tabular}

Source: data processed (2020)

Tabel 3.3 (b) Discriminant Validity Test Result

\begin{tabular}{|l|l|l|l|l|}
\hline Variable & VAVE & Exp-K & Tacit-K & VE \\
\hline Exp-K & 0.773 & 1.000 & 0.653 & 0.674 \\
\hline Tacit-K & 0.757 & 0.653 & 1.000 & 0.615 \\
\hline VE & 0.867 & 0.674 & 0.615 & 1.000 \\
\hline
\end{tabular}

Source: data processed (2020)

The test results in Table 3.3 (a) and Table 3.3 (b) shows that all AVE roots on research variables has a value greater than the latent value of the correlation variable. So it can be concluded that this measurement meet validity requirements discriminant.

\section{B. Evaluation of structural models (inner model) with Gooness of Fit Model}

Goodness of Fit (GoF) Testing structural models in the inner model use predictive-relevance value $\left(\mathrm{Q}^{2}\right)$ to conduct a test of the variables used in the model so that we can know how much the influence of exogenous variables on endogenous variables. $R^{2}$ value of each endogenous variable in the study this can be seen in Table 3.4. following.
Table 3.4 R $\mathrm{R}^{2}$ Value of Endogenous Variables

\begin{tabular}{|l|l|}
\hline Dependent variable & R-square \\
\hline Exp-K & 0.426 \\
\hline VE & 0.507 \\
\hline
\end{tabular}

Source: data processed (2020)

Nilai $\mathrm{Q}^{2}$ predictive relevance, diperoleh dengan rumus :

$$
\begin{aligned}
\mathrm{Q}^{2} & =1-\left(1-\mathrm{R} 1^{2}\right)\left(1-\mathrm{R} 2^{2}\right) \\
& =1-(1-0.426)(1-0.507) \\
& =1-(0.574)(0.493) \\
& =1-0.283 \\
& =0.717
\end{aligned}
$$

Calculation results show predictive relevance value of 0.717 (>0). That means that $71.70 \%$ variation on the value engineering variable (dependent variable) can be explained by the variables used in the research model that is tacit knowledge and explicit knowledge

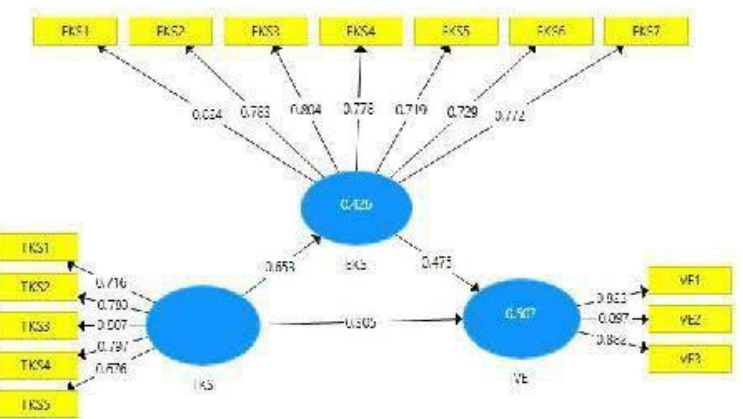

Figure 3.1 Output results Partial Least Square (PLS) Source: data processed (2020)

The results of data analysis in Figure 3.1 by using PLS shows that the loading factor indicator coefficient for each variable inside the model has a value above 0.5 .

\section{Hypothesis Testing Results Research}

Hypothesis testing results with the Partial Least structural equation model square is shown in Figure 3.2 below this.

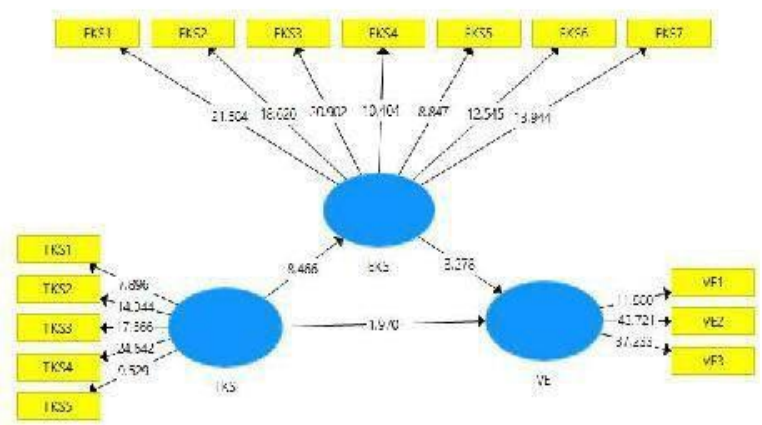

Figure 3.2 Partial Least Square (PLS) Output (after bootstrapping)

Source: data processed (2020)

Figure 3.2 shows that hypothesis (H1), which states that: Tacit knowledge in perspective manacika has positive influence and significant impact on the value engineering of 
construction projects in Bali acceptable. Likewise hypothesis (H2) which states that tacit knowledge in manacika's perspective positive and significant effect of explicit knowledge in kayika and wacika perspective can be accepted. Hypothesis (H3) is explicit knowledge in the perspective of wacika and kayika has a positive and significant effect on the value engineering of construction projects in Bali be accepted. Hypothesis (H4) which states that explicit knowledge mediate the relationship of tacit knowledge in manacika's perspective with value engineering construction projects in Bali meet criteria as partial mediation. The results of testing the hypothesis shown in Table 3.5 below.

Table 3.5 Hypothesis Test Results

\begin{tabular}{|l|l|l|l|l|l|}
\multicolumn{2}{c|}{ Table 3.5 Hypothesis Test Results } \\
\hline $\begin{array}{l}\text { Relationship } \\
\text { vetween }\end{array}$ & $\begin{array}{l}\text { Origina } \\
\text { variables } \\
\text { sample } \\
(\mathrm{O})\end{array}$ & $\begin{array}{l}\text { Samp } \\
\text { le } \\
\text { mean } \\
(\mathrm{M})\end{array}$ & $\begin{array}{l}\text { T- } \\
\text { Statisti } \\
\mathrm{c}\end{array}$ & $\begin{array}{l}\text { P } \\
\text { Value }\end{array}$ & Inf \\
\hline ExpK-VE & 0.475 & 0.465 & 3.278 & 0.001 & Sig \\
\hline TK-ExpK & 0.653 & 0.655 & 8.466 & 0.000 & Sig \\
\hline TK-VE & 0.305 & 0.322 & 1.970 & 0.049 & Sig \\
\hline
\end{tabular}

Source: data processed (2020)

The results of the analysis show that tacit knowledge based on manacika's perspective has a positive and significant impact on the value engineering of construction projects (a). These results indicate that tacit knowledge is based on the manacika perspective perceived by the project contractor in Bali and is measured based on indicators: ideas, perceptions, ways of thinking, insights, expertise, and their experience as learning, proved capable improve value engineering, which is measured based on indicators of project benefits and costs.

Tacit knowledge has a significant positive effect on explicit knowledge (b). This indicates that tacit knowledge is based on perspective manacika perceived by the project contractor in Bali and measured based on indicators: ideas, perceptions, ways of thinking, insights, expertise, and experience as learning they are proven to be able to increase explicit knowledge, which is measured based on documented knowledge indicators, easily stored, propagated, disseminated, communicated and studied with the understanding of the project contractor.

The results of the analysis regarding the effect of explicit knowledge on the value engineering of construction projects show positive and significant results (c). This indicates that explicit knowledge in the perspective of kayika and wacika is based on indicators: knowledge that is documented, easily stored, propagated, disseminated, communicated and studied with the understanding of the project contractor, proved capable improve value engineering, which is measured based on indicators of project benefits and costs.
Whereas the results of the specific analysis of the effect on PLS output, which explains the relationship of explicit knowledge mediating tacit knowledge to value engineering occur significantly, with a Pvalue of 0.001 with the mediating role being partial. The hypothesis is tested by the following calculation

$$
\begin{aligned}
& \mathrm{d}=\mathrm{a}+(\mathrm{b} \times \mathrm{c}) \\
& =0.305+(0.653 \times 0.475) \\
& =0.305+0.31 \\
& =0.615
\end{aligned}
$$

The results of these calculations indicate that the mediating relationship (d) has a greater value (0.615) than the direct relationship (a) that is equal to 0.305 . In addition, the method of testing mediation variables that are used in accordance with the criteria [24] include: if $a, b$, and c are significant but the value of direct expertise $a<c$, then it is said to be partial mediation. The results of the analysis of the influence of explicit knowledge in the perspective of wacika and kayika partially mediate (partial mediation) tacit knowledge in the manacika perspective with the value engineering of construction projects.

\section{CONCLUSION}

Based on the results of the analysis of research data, that tacit and explicit knowledge have a significant influence on the value engineering of construction projects. Explicit knowledge acts as a partial mediation between tacit knowledge to value engineering on the understanding of construction project contractors in Bali. The results of this study are in line with that tacit knowledge is one of the important assets in the construction industry, because of its significant role in driving innovation and creating value; [16], according [18] in the form of knowledge in a company must enable the conversion of knowledge from tacit to explicit knowledge. Research from [20], which examines the influence of tacit knowledge which is one component of knowledge sharing on the ability of innovation.

\section{REFERENCES}

[1] Nonaka, I., and Takeuchi, H. (1995) €How Japanese companies create the dynamics of innovation•, in The knowledge-creating company. New York: Oxford University Press.

[2] Laudon, K. C. and J. P. L. (2002) Management information systems: Managing the digital firm. 7 th ed. New Jersey: Prentice-Hall.

[3] Halawi, L.A., McCarthy, R.V., Aronson, J. E. (2006) €Knowledge management and the competitive strategy of the firm • , The Learning Organization, 13, pp. 384-397.

[4] Malhotra, Y. (2000) €From Information Management To Knowledge Management : Beyond the "Hi-Tech Hidebound" Systems•

[5] Serrat, B. O. (2009) €Understanding and Developing Emotional Intelligence• , (June).

[6] Suhardana, K. M. (2007) Tri Kaya Parisudha: Bahan Kajian untuk Berpikir Baik, Berkata Baik, dan Berbuat Baik. Surabaya: Paramita.

[7] Berawi, M.A. (2009d), Process and Product Optimization Using Value Engineering/Value Management - Editorial Note, Value World, Journal of the Society of American Value Engineers (SAVE) International, Volume: 32, Number: 2, pp. 2-3, Summer 2009, SAVE International Press, USA

[8] Lin, H. . (2007) €Knowledge Sharing and Firm Innovation Capability: An Empirical Study', International Journal of Manpower, 28((3)), pp. 315-332. 
[9] Wang, S., and Noe, R. A. (2010) €Knowledge sharing: A review and directions for future research , Human Resource Management Review., 20, pp. 115-131.

[10] Cooke, T. (2013) €Can knowledge sharing mitigate the effect of construction project complexity? • Construction Innovation. Emerald, 13(1), pp. 5-9. doi: 10.1108/14714171311296093.

[11] Loforte Ribeiro, F. (2009) €Enhancing knowledge management in construction firms• , Construction Innovation. Emerald, 9(3), pp. 268-284. doi: 10.1108/14714170910973493.

[12] Liao, S., Fei, W. and Chen, C. (2007) €Knowledge sharing , absorptive capacity, and innovation capability: an empirical study of Taiwan • s knowledge-• , Journal of Manpower, 28((3)), pp. 315-332. doi: 10.1177/0165551506070739.

[13] Jalal, H.A., Toulson, P., and T. . (2013) €Knowledge Sharing Success For Sustaining Organizational Competitive Advantage• , Procedia Economics and Finance, 7, pp. 150-157.

[14] Rega S Kathiravelua, Nur Naha Abu Mansorb, T.Ramayahc , Norhalimah Idrisd (2014) €Why Organisational Culture Drives Knowledge Sharing?', Procedia - Social and Behavioral Sciences. Elsevier B.V., 129, pp. 119-126. doi: 10.1016/j.sbspro.2014.03.656.

[15] Ofori, D, Abraham Osei, Shadrach Ato - Mensah, (2015) €Innovation and Knowledge Sharing: A New Competitive Advantage in the Mobile Telecommunication Industry in Ghana • , 3(5), pp. 157-163. doi: 10.11648/j.sjbm.20150305.14

[16] Chinowsky, P., C. (2007) €Knowledge management to learning organization connection• , J. Manage. Eng, pp. 122-130. doi: 10.1061/(ASCE)0742-597X(2007)23:3(122).

[17] Jeong-Han Woo, Mark J. Clayton, Robert E. Johnson, Benito E. Flores, Christopher Ellis Department, (2004) €Dynamic Knowledge Map : reusing experts ' tacit knowledge in the AEC industry', 13, pp. 203-205. doi: 10.1016/j.autcon.2003.09.003.

[18] Malone, D. (2002) €Knowledge management. A model for organizational learning $\bullet$, International Journal of Accounting Information Systems, 3(2), pp. 111-123. doi: 10.1016/S14670895(02)00039-8.

[19] Wang, Z. and Wang, N. (2012) €Knowledge Sharing, Innovation And Firm Performance , Expert Systems With Applications. Elsevier Ltd, 39(10), pp. 8899-8908. doi: 10.1016/j.eswa.2012.02.017.

[20] Alwis, R. S. and Hartmann, E. (2008) €The use of tacit knowledge within innovative companies: knowledge management in innovative enterprises• , Journal of Knowledge Management, 12(1), pp. 133147. doi: $10.1108 / 13673270810852449$.

[21] Dwi Widyani, A. (2015) €Knowledge Management Dalam Perspektif Tri kaya Parisudha Serta Pengaruhnya Terhadap Kinerja Pengurus Koperasi・ ,5(2).

[22] Soeharto,Iman, "Manajemen Proyek (Dari Konseptual Sampai Operasional)”, Erlangga, Jakarta 1999.

[23] Ghozali, I. and Latan, H. (2012) Partial Least Square Konsep, Teknik dan Aplikasi Menggunakan Program SmartPLS 2.0 M3. Semarang: Universitas Diponegoro.

[24] Hair JF, Black WC, Babin BJ, A. R. (2010) Multivariate data analysis: a global perspectives. 7th ed. Edited by P. Education. New Jersey. 